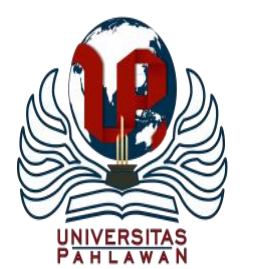

Jurnal Abdidas Volume 2 Nomor 4 Tahun 2021 Halaman 894-902

JURNAL ABDIDAS

http://abdidas.org/index.php/abdidas

\title{
Implementasi Metode Home Visit untuk Meningkatkan Motivasi Belajar Siswa SD pada Masa Pandemik Covid-19
}

\author{
Teguh Prasetyo ${ }^{1}$, Endin Mujahidin ${ }^{2}$, Rasmitadila $^{3}$, Aprillia Kumala Yuani ${ }^{4}$ \\ Pendidikan Guru Sekolah Dasar, Universitas Djuanda Bogor, Indonesia ${ }^{1,3,4}$ \\ Pascasarjana, Universitas Ibn Khaldun Bogor, Indonesia ${ }^{2}$ \\ E-mail: teguh@unida.ac.id ${ }^{1}$, mujahidin.endin@gmail.com ${ }^{2}$, rasmitadila@unida.ac.id $^{3}$, \\ aprilliakumala.1998@ gmail.com ${ }^{4}$
}

\begin{abstract}
Abstrak
Artikel ini merupakan implementasi pengabdian kepada masyarakat pada masa pandemik untuk siswa usia sekolah dasar dengan menerapkan metode home visit. Sebelumnya, pembelajaran siswa SDN Gelaran I Gunungkidul, Yogyakarta hanya menggunakan pembelajaran daring, sehingga siswa menjadi bosan dan monoton. Metode home visit menjadi alternatif pembelajaran yang diselenggarakan sekolah pada masa pandemi Covid-19. Program dari sekolah yang dilaksanakan dengan cara guru mendatangi salah satu rumah siswa yang sudah dikelompokkan menjadi kelompok kecil yaitu terdiri dari 10 orang sesuai dengan jarak rumah yang berdekatan. Pelaksanaan home visit tetap mengedepankan protokol kesehatan di tengah pandemik tahun 2020. Tujuan dari pelaksanaan penerapan metode home visit yaitu untuk mengurangi dampak dari pandemi Covid-19 dan membuat siswa menjadi termotivasi untuk belajar selama di rumah. Pelaksanaan home visit dilakukan setiap satu minggu sekali pertemuan yaitu pada hari Rabu dengan kunjungan guru pada bulan Agustus 2020. Metode home visit membuat siswa menjadi termotivasi untuk belajar, sehingga dapat meningkatkan hasil belajar dan menyenangkan siswa. Selain itu, orang tua dapat dengan mudahnya siswa dapat bertanya langsung dengan guru ketika materi belajar tidak jelas.
\end{abstract}

Kata kunci: masa pandemi Covid-19, metode home visit, motivasi belajar, sekolah dasar

Abstract

This article is implementation community service in the pandemic period for elementary school-age students by applying the home visit method. Previously the learning of students of Elementary School I Gunungkidul, Yogyakarta only used online learning so that students become bored and monotonous. Home visit method is alternative learning organized during the Covid-19 pandemic period. The program from the school was carried out by the way the teacher came to one of the houses of students who have been grouped into small groups, namely consisting of 10 people according to the distance of nearby houses. The implementation of home visit continues to prioritize health protocols in the middle of a pandemic in 2020. The purpose of the implementation of the application of the home visit method is to reduce the impact of the Covid-19 pandemic and make students motivated to study while at home. The home visit implementation is carried out every week the meeting is on Wednesday with teacher's visit in August 2020. The home visit method makes students motivated to learn so that it can improve learning outcomes and please students. In addition, parents can easily be students can ask directly with the teacher when the learning material is unclear.

Keywords: elementary school, home visit method, learning motivation, pandemic covid-19 period

Copyright (c) 2021 Teguh Prasetyo, Endin Mujahidin, Rasmitadila, Aprillia Kumala Yuani

$\square$ Corresponding author :

Address : Jln. Tol Ciawi No.1, Ciawi-Bogor, Jawa Barat

Email : teguh@unida.ac.id

DOI : $\quad$ https://doi.org/10.31004/abdidas.v2i4.388

ISSN 2721- 9224 (Media Cetak)

ISSN 2721- 9216 (Media Online) 
895 Implementasi Metode Home Visit untuk Meningkatkan Motivasi Belajar Siswa SD pada Masa Pandemik Covid-19- Teguh Prasetyo, Endin Mujahidin, Rasmitadila, Aprillia Kumala Yuani

DOI: https://doi.org/10.31004/abdidas.v2i4.388

\section{PENDAHULUAN}

Pandemik Covid-19 menyerang sistem imun tubuh dan membatasi sistem pernapasan manusia yang diiringi batuk dan pilek yang semakin hari membuat badan menjadi lemah sampai susah dalam pernapasan. Virus Covid-19 tidak hanya melanda di Indonesia saja, tetapi sudah menjadi wabah bencana global dan mendunia yang menyerang seluruh dunia. Wabah ini berdampak pada berbagai aspek termasuk pada bidang pendidikan.

Dampak dibidang pendidikan bagi pihak sekolah pada tahun 2020, yakni sekolah mengalami perubahan sistem pembelajaran dikarenakan adanya wabah Covid-19 yang menyebabkan aktivitas pembelajaran menjadi berbeda dengan tahun-tahun sebelumnya. Adanya pergantian sistem pembelajaran daring menimbulkan perbincangan dan adaptasi baru terhadap proses pembelajaran. Tentu saja, hal ini salah satunya berdampak pada terganggunya sistem penyesuaian sosial siswa dan guru dalam pembelajaran.

Pelaksanaan pembelajaran tradisional yang biasa dilakukan di kelas sudah pasti membantu siswa dalam memahami suatu mata pelajaran. Proses pembelajaran harus dirancang secara yang kondusif dan menyenangkan serta memberikan kesempatan siswa untuk menemukan tujuan capaian pembelajaran secara mandiri. Tetapi tantangan penerapan Pembelajaran Jarak Jauh (PJJ) dan dalam jaringan (daring) siswa menjadi kurang bergairah dalam belajar apalagi ketika mengalami kesulitan dalam belajar. Pembelajaran daring pada masa pandemi Covid-19 sangat mempengaruhi minat atau atensi belajar siswa karena tidak dapat berjumpa teman-teman sebaya dan guru secara langsung sehingga siswa merasa bosan (Yunitasari \& Hanifah, 2020).

\section{Berdasarkan Surat Edaran Pemerintah} Indonesia Nomor 03/KB Tahun 2020 menyatakan bahwa aktivitas pembelajaran di sekolah baik jenjang perguruan tinggi, sekolah menengah atas, sekolah menengah pertama, sekolah dasar hingga pendidikan anak usia dini memberlakukan Pembelajaran di Rumah (BDR) dengan sistem dalam jaringan atau pembelajaran daring bagi daerah zona merah dan hijau (SKB Mendikbud, Menag, Menkes, Dan Mendagri RI, 2020). Sedangkan pembelajaran tatap muka dan bergiliran atau (shifting) dilakukan bagi daerah kuning.

Proses belajar siswa yang ideal harus ada hubungan timbal balik yang berlangsung dalam suasana edukatif untuk mencapai tujuan tertentu. Hubungan timbal balik antara guru dan siswa adalah syarat utama berlangsungnya proses pembelajaran di kelas. Selanjutnya pola interaksi pengajaran ini bersifat verbal, adanya saling hubungan timbal balik yang bersifat positif sehingga dapat pengaruhi hasil pengajaran (Afandi et al., 2013). Lebih lanjut pembelajaran daring memiliki batasan proses interaksi guru dan siswa, beberapa kelemahan pembelajaran secara daring yakni: 1) terbatasnya ruang interaksi siswa dengan siswa, siswa dengan guru, 2) hambatan jaringan internet, 3) siswa lebih cenderung membuka aplikasi lain saat pembelajaran berlangsung, 4) guru diharuskan menguasai ICT (Information Communication Technology) (Rahmania et al., 2021). 
896 Implementasi Metode Home Visit untuk Meningkatkan Motivasi Belajar Siswa SD pada Masa Pandemik Covid-19- Teguh Prasetyo, Endin Mujahidin, Rasmitadila, Aprillia Kumala Yuani

DOI: https://doi.org/10.31004/abdidas.v2i4.388

Penggunaan metode yang tepat pada suasana pandemik Covid-19 saat ini sangat berpengaruh terhadap hasil belajar siswa. Dimana metode pembelajaran yang digunakan harus sesuai dengan kondisi siswa dan ketetapan materi yang diajarkan guru. Penggunaan metode pembelajaran dalam proses pembelajaran yaitu untuk mencapai tujuan pembelajaran siswa harus dibuat secara sistematis dan terencana. Metode pembelajaran daring yang disusun harus dapat memfasilitasi belajar siswa di masa pembelajaran daring.

Pembelajaran PJJ pada masa pandemi Covid-19 menimbulkan perubahan pada sistem belajar yang dapat mempengaruhi proses belajar siswa dan respons terhadap materi pelajaran (Basar, 2021). Kemudian masalah yang dihadapi siswa menjadi gangguan motivasi dalam berprestasi dan interaksi pembelajaran menjadi tidak optimal. Kegiatan pengabdian di masa pandemik dapat membantu siswa dalam memahami materi selama pembelajaran daring. Proses pembelajaran tatap muka dengan menjaga protokol kesehatan dapat meningkatkan motivasi siswa belajar, misalnya melalui penggunaan metode drill yang efektif pada materi bangun data dan mudah dipahami siswa (Isnurani et al., 2021).

Dalam rangka kegiatan pengabdian melalui program KKN Adaptasi Kebiasaan Baru FKIP Unida Bogor pada tahun 2020 dilaksanakan di Desa Bejiharjo Kecamatan Karangmojo Gunungkidul dengan mencakup di bidang pendidikan. Salah satu program kerja pengabdian yang dilakukan Program Studi Pendidikan Guru Sekolah Dasar FKIP Universitas Djuanda Bogor berupa Program Mengajar di SDN Gelaran I
Bejiharjo dengan siswa kelas V. Pengabdian kepada masyarakat melalui program mata kuliah KKN AKB pada masa pandemik Covid-19, tentu bukan hal yang mudah karena mahasiswa harus menyiapkan fisik, mental, dan kesehatan yang baik (Prasetyo et al., 2020). Selain itu, penting dosen dan mahasiswa sebagai agen pembaharu sekaligus calon sarjana pendidikan untuk berperan dan terlibat secara aktif dalam pengabdian pada masyarakat secara langsung, misalnya dengan metode home visit.

Kegiatan home visit yang dilakukan guru merupakan sarana untuk memberikan pelayanan dan menginformasikan kepada orang tua anak terkait usaha-usaha yang harus dilakukan orang tua dalam mendukung pengembangan seluruh potensi, minat, dan bakat siswa selama di rumah. Orang tua tidak menguasai pengetahuan tentang perkembangan anak sehingga dibutuhkan lembaga yang dapat memberikan stimulus dan memantau tahap perkembangan anak (Nirmala \& Annuar, 2020). Pelaksanaan metode home visit memerlukan perencanaan yang matang dari guru dan memerlukan kerja sama yang baik dengan orang tua siswa serta atas persetujuan kepala sekolah (Mokodompit, 2020).

Metode home visit dalam pembelajaran pada saat pandemi saat ini dimaksudkan untuk memotivasi belajar siswa dan mengantisipasi penyebaran Covid-19 di lingkungan masyarakat. Metode home visit membuat siswa tidak jenuh karena pembelajaran sebelumnya melalui daring. Namun metode home visit perlu memperoleh dukungan dari semua pihak mulai dari kepala sekolah, pengawas sekolah, guru, orang tua, dan 
897 Implementasi Metode Home Visit untuk Meningkatkan Motivasi Belajar Siswa SD pada Masa Pandemik Covid-19- Teguh Prasetyo, Endin Mujahidin, Rasmitadila, Aprillia Kumala Yuani DOI: https://doi.org/10.31004/abdidas.v2i4.388

komite sekolah serta ketersediaan rumah siswa yang luas dan mudah dijangkau bagi siswa (Pambudi et al., 2021). Home visit merupakan kegiatan bantuan pembelajaran yang dilakukan guru dengan datang ke rumah untuk membantu siswa dalam proses pembelajaran. Tujuan home visit dalam membantu untuk memperoleh berbagai data yang diperlukan guru untuk membantu siswa dalam memahami lingkungan atau pemecahan masalah yang telah dialami siswa saat belajar dari rumah.

\section{METODE}

Metode pelaksanaan pengabdian kepada masyarakat meliputi kegiatan perencanaan, pelaksanaan, dan evaluasi sesuai rancangan pada matriks KKN AKB yang disusun sebelumnya. Pada awal perencanaan kegiatan akan dilaksanakan pembelajaran siswa secara luring di sekolah, tetapi karena tidak mendapatkan izin dari pangawas sekolah maka kegiatan dialihkan pada pembelajaran daring dari sekolah. Penerapan pelaksanaan daring dilakukan selama satu bulan akhirnya muncul inovasi penerapan belajar home visit dengan menggunakan metode eksperimen.

Pelaksanaan eksperimen dilakukan pada kelas 5 SDN Gelaran I tepatnya di Desa Bejiharjo Gunungkidul D.I. Yogyakarta. Pelaksanaan metode home visit dilakukan dengan sejumlah ketentuan pelaksanaan dimana dilakukan satu kali pertemuan setiap hari Rabu antara pukul 07.3012.00 WIB. Adapun pembagian kelompok kecil yang berjumlah 10 orang ditentukan berdasarkan jarak tempat tinggal yang dianggap berdekatan.
Pelaksanaan penerapan metode pembelajaran ini dilakukan pada bulan Agustus 2020.

Data pelaksanaan program pengabdian kepada masyarakat tentang metode home visit diperoleh dari hasil observasi dan wawancara dengan narasumber orang tua, siswa, dan guru tanpa ada paksaan dan rekayasa dari kejadian pembelajaran sebelumnya. Adapun kegiatan evaluasi metode home visit dilakukan berdasarkan refleksi mahasiswa, guru, dan pihak orang tua selama program pengabdian masyarakat ini berlangsung.

\section{HASIL DAN PEMBAHASAN}

SDN Gelaran I kelas V berjumlah 30 siswa. SDN Gelaran I terletak di Bejiharjo, Karangmojo, Gunungkidul, Yogyakarta. Sebelum diadakannya metode home visit SDN Gelaran I menggunakan kombinasi Daring dan Luring. Pembelajaran daring di SDN Gelaran I dilaksanakan pada hari Senin-Jumat dimana guru memberikan tugas atau materi setiap hari yang disesuaikan dengan jadwal pembelajaran yaitu soal maupun materi sudah disiapkan atau diunggah melalui aplikasi Google Classroom maupun WhatsApp Group (WAG) kelas V SDN Gelaran I.

Pembelajaran Luar Jaringan (Luring) dilaksanakan dengan pendampingan orang tua siswa dan guru memantau pembelajaran melalui WAG. Di mana siswa maupun guru dipersilahkan berkomunikasi dengan guru jika mengalami kesulitan dengan materi yang diberikan dan jika adanya kendala belajar melalui WAG. Sementara pembelajaran dilaksanakan di rumah siswa mulai dari hari Senin sampai Jumat. Dengan cara guru 
898 Implementasi Metode Home Visit untuk Meningkatkan Motivasi Belajar Siswa SD pada Masa Pandemik Covid-19- Teguh Prasetyo, Endin Mujahidin, Rasmitadila, Aprillia Kumala Yuani

DOI: https://doi.org/10.31004/abdidas.v2i4.388

memberikan materi belajar mandiri atu tugas yang berasal dari buku siswa, yakni satu subtema selama satu minggu. Orang tua siswa akan mengambil di sekolah dan setelah itu dikumpulkan setiap hari Senin pada awal pekan dan ditukar lagi dengan penugasan atau soal baru.

Cara ini dianggap kurang efektif sehingga guru membuatkan soal setiap hari dan siswa menukar soal sekalian mengumpulkan jawaban, cara ini dibuat karena tentunya siswa banyak yang sudah merindukan sekolah dengan cara ini guru membuat anak menjadi mengetahui suasana baru dan sekalian melihat sekolah. Kemudian untuk menanyakan adakah kesulitan dalam memahami materi maupun mengerjakannya. Ternyata cara ini dirasa banyaknya keluhan dari orangtua atau siswa meminta untuk adanya pembelajaran secara tatap muka.

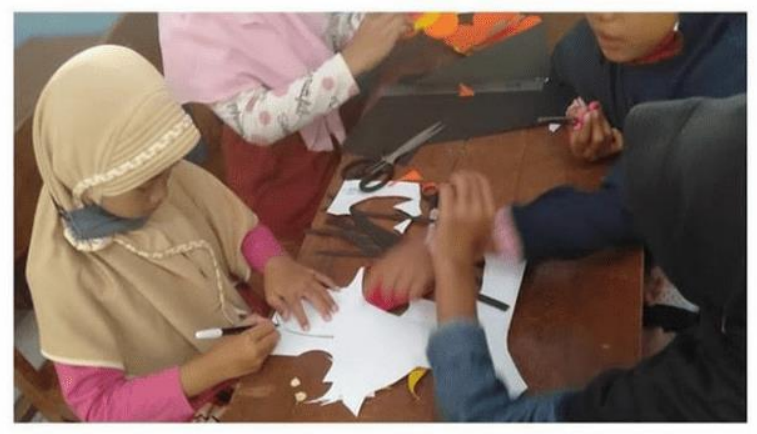

Gambar 1. Dokumentasi Kegiatan Aktivitas Pembelajaran Luring di Sekolah

Satu bulan sudah diterapkan pembelajaran daring dan luring akan tetapi hasil evaluasi suasana tidak bisa dilanjutkan dikarenakan faktor Desa Bejiharjo adalah desa wisata. Banyak wisatawan baru datang sehingga dirasa kurang efektif jika anak-anak harus keluar rumah sehingga pihak sekolah berunding untuk mencari jalan keluar sebagai solusi untuk mengatasi suatu masalah yaitu dengan diadakannya home visit.

Pembelajaran daring dilakukan sejak pandemi Covid-19 tidak diperbolehkan melakukan pembelajaran tatap muka, karena wilayah Gunungkidul masih zona merah banyak pertimbangan yaitu situasi dan kondisi yang tidak memungkinkan untuk membuat kerumunan dalam jumlah banyak, anjuran dari pemerintah berkaitan dengan penjelasan pembelajaran, dan kekhawatiran sekolah mengenai kesehatan siswa. Sehingga pihak sekolah SDN Gelaran I menggunakan metode home visit. Keputusan ini sudah disetujui oleh orang tua, pihak sekolah, dan pengawas.

Berdasarkan hasil yang telah dilakukan selama penerapan home visit di SDN Gelaran I. Ditemukan beberapa fakta-fakta menarik terhadap proses pembelajaran yang telah dilakukan selama kegiatan berlangsung. Seperti halnya jarak antara siswa satu dengan siswa yang lain sangatlah berjauhan dan untuk menuju ke salah satu rumah tentunya tidak mudah. Akan tetapi sambutan dari orang tua dan lingkungan masyarakat yang membuat jadi semangat serta dukungan untuk tetap melakukan pembelajaran home visit.

Keputusan menggunakan metode pembelajaran home visit telah disetujui orang tua/wali siswa dan pihak sekolah karena dirasa metode ini sangat efektif karena siswa mendapatkan mata pelajaran langsung secara tatap muka seperti pembelajaran di sekolah. Dengan begitu siswa mudah dalam menyerap ilmu yang dijelaskan oleh guru seperti halnya pembelajaran Matematika, mata pelajaran ini dianggap cukup 
rumit jika tidak adanya pembelajaran secara tatap muka dan guru menjelaskan langsung karena jika hanya melalui daring sisiwa masih kebingungan untuk memahami penyampaian materi tersebut.

Banyak ditemukan kasus siswa selama saya mengajar di SDN Gelaran I siswa yang belum bisa mengalikan dua angka ataupun pembagian tiga angka dan masih kebingungan dalam menyederhanakan pecahan maupun mencari FPB, jika guru tidak mengajar atau mendampingi secara guru turun tangan yaitu menggunakan metode home visit maka akan fatal karena di rumah peserta didik tidak belajar kebanyakan hanya main dan acuh terhadap tugas yang diberikan secara daring.

Metode home visit para siswa dapat mendapatkan pembelajaran secara visual atau audio karena tidak semua siswa dapat menguasai salah satu metode online seperti halnya Google Classroom maupun WAG. Di mana masih terdapat beberapa siswa yang cara belajarnya harus melihat guru menulis dan menjelaskan langsung sehingga siswa bisa menangkap penjelasan guru secara tatap muka.

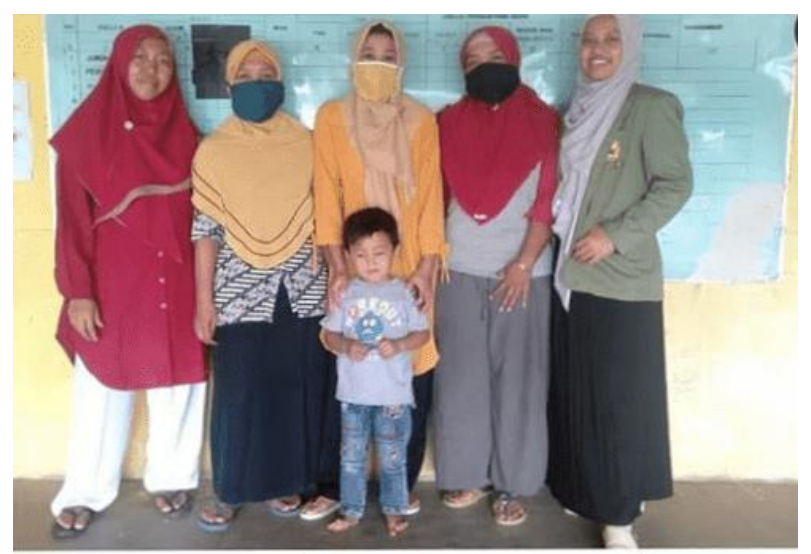

Gambar 2. Kegiatan Home Visit bersama Orang Tua Wali Siswa
Metode home visit sudah dipersiapkan oleh Guru SDN Gelaran I, harapan alternatif metode ini dapat terlaksana dengan baik. Selanjutnya metode home visit diatur dengan sejumlah peraturan pelaksanaan, dimana metode dilaksanakan $1 \mathrm{x}$ dalam seminggu yaitu pada hari Rabu, pukul 07.30-12.00 WIB. Keunggulan metode home visit dapat memenuhi kebutuhan siswa dalam melakukan pembelajaran secara langsung. Walaupun tidak secara optimal karena alokasi waktu pertemuan yang dilakukan guru dan siswa dan batasan pelaksanaan pertemuan tatap muka dengan metode bergiliran atau per kelompok belajar menyesuaikan lokasi rumah (Makmun, 2021).

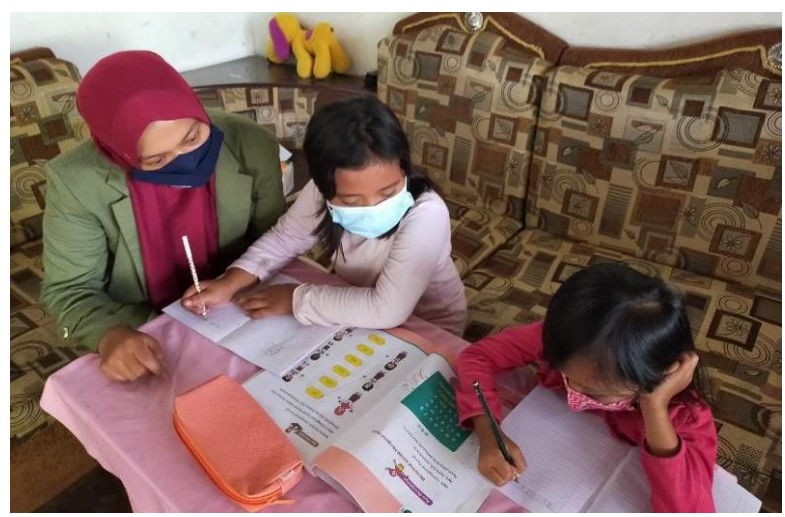

Gambar 3. Pendampingan Belajar Siswa dengan Metode Home Visit

Metode home visit diterapkan pada masa pandemi saat ini tentunya sangat memudahkan siswa dalam memahami materi. Siswa yang mengalami kesulitan belajar dengan mudahnya siswa dapat bertanya langsung dan dijelaskan langsung oleh guru. Hal ini tentu berbeda ketika pembelajaran daring siswa maupun orang tua tentunya mengalami banyak kendala sedangkan 
900 Implementasi Metode Home Visit untuk Meningkatkan Motivasi Belajar Siswa SD pada Masa Pandemik Covid-19- Teguh Prasetyo, Endin Mujahidin, Rasmitadila, Aprillia Kumala Yuani

DOI: https://doi.org/10.31004/abdidas.v2i4.388

jika bertanya tentunya guru tidak bisa dengan waktu bersamaan bisa menjawab. Pembelajaran daring dapat dikombinasikan dengan program home visit sebagai penguatan media daring, menyampaikan materi dan informasi pembelajaran aplikasi WhatsApp. Adanya tindak lanjut guru mengunjungi ke rumah-rumah siswa untuk melakukan pembelajaran tatap muka atau home visit (Makmun, 2021).

Implementasi metode home visit guru ini berharap dapat berkembang di seluruh Kabupaten Gunungkidul pada masa pandemi Covid-19 ini, di mana agar siswa tetap mendapatkan pendidikan yang layak dan mudah dipahami. Hasil temuan lain menunjukkan bahwa home visit sebagai metode pembelajaran yang dapat membantu kesulitan siswa dengan materi yang sederhana dan praktis. Metode home visit ini dapat diterapkan di SDN dengan kategori baik, jika dilaksanakan secara bergantian dengan rombel 4-5 siswa (Pambudi et al., 2021).

Penggunaan metode pembelajaran pada pandemik saat ini sangat dibutuhkan untuk keberhasilan pendidikan di masa sekarang dengan memperhatikan situasi dan kondisi siswa. Jika hanya menggunakan pembelajaran secara daring membuat siswa menjadi jenuh dan tidak semangat karena dianggap pembelajaran daring monoton. Masih terdapat siswa yang tidak dapat mengikuti pembelajaran secara daring dikarenakan faktor perekonomian dan tempat tinggal peserta didik yang sulit dijangkau jaringan internet. Pendekatan berkunjung ke rumah siswa ini dapat membantu siswa memahami materi dan guru terus membimbing penggunaan teknologi pembelajaran daring siswa (Ota et al., 2021). Penggunaan pembelajaran daring dengan media audio visual dapat memudahkan siswa memahami materi yang diberikan guru. Media audio visual mempermudah siswa untuk mengerjakan tugas, sehingga siswa memiliki perhatian lebih terhadap materi pelajaran (Puteri et al., 2020).

Implementasi program home visit dapat dikomunikasikan dengan santai sekaligus menjalin keakraban antara guru dan orang tua siswa serta memperoleh informasi yang akurat mengenai kesulitan belajar siswa baik di sekolah maupun di rumah (Syifa' et al., 2020). Banyak faktor yang mengharuskan orang tua tidak dapat mendampingi anak belajar di rumah yaitu pertama faktor ekonomi yang mengharuskan orang tua harus mencari nafkah untuk anaknya dan juga banyak lagi alasan dimana latar belakang orang tua yang kurang seperti halnya orang tua siswa yang lulusan SD maupun kurangnya pengetahuan sehingga orang tua kesulitan dalam mengajari anak di rumah.

Selain itu, faktor kesibukan orang tua wali siswa, banyak yang berprofesi sebagai petani, pedagang, guru, dan lain-lainnya. Orang tua yang berprofesi guru sendiri juga memiliki tugas mengajar anak didiknya di sekolah sehingga tugas anak sendiri menjadi terbengkalai selama pembelajaran daring di rumah. Faktor-faktor yang dapat menjadi penghambat home visit guru yakni: kurang disiplin siswa dan keterbatasan waktu belajar mengajar (Mahendra et al., 2021).

Berhasil atau tidaknya metode home visit sangat tergantung pada aktivitas siswa mengikuti pembelajaran ini. berdasarkan hasil penelitian 
901 Implementasi Metode Home Visit untuk Meningkatkan Motivasi Belajar Siswa SD pada Masa Pandemik Covid-19- Teguh Prasetyo, Endin Mujahidin, Rasmitadila, Aprillia Kumala Yuani

DOI: https://doi.org/10.31004/abdidas.v2i4.388

implementasi home visit, siswa yang sebelumnya pasif menjadi aktif sehingga minat belajar siswa pada pelajaran tinggi (Husnuzzakiya et al., 2021). Pada aspek motivasi belajar siswa lebih tinggi dan signifikan penerapan metode home visit guru jika dibandingkan dengan pembelajaran daring seperti umumnya (Yusrizal et al., 2020).

Kegiatan pendampingan orang tua sangatlah berpengaruh terhadap keberhasilan siswa karena pada situasi seperti ini orang tualah yang membantu guru untuk saling bekerjasama demi suatu ketercapaian pendidikan dan berjalan dengan baik. Akan tetapi orangtua maupun wali masih acuh dan hanya diserahkan kepada guru tanpa adanya pendampingan kepada anaknya. Sehingga siswa menggangap ini liburan bukan sekolah. Metode home visit juga membantu guru dalam pelayanan Bimbingan Konseling (BK) belajar siswa, sehingga psikologi belajar siswa dapat berkembang secara optimal. Selanjutnya dampak penerapan home visit, diharapkan dapat membantu pemecahan masalah dan bimbingan konseling siswa dengan tetap penekanan pada asas kerahasiaan yang dilakukan guru (Handayani \& Hidayat, 2017).

\section{SIMPULAN}

Berdasarkan hasil dan pembahasan implementasi metode home visit membuat siswa menjadi termotivasi untuk belajar sehingga dapat meningkatkan hasil belajar siswa selama di rumah. Metode home visit membuat siswa menjadi senang karena pembelajaran tidak monoton dan menciptakan suasana baru bagi siswa. Hal lain yang diperoleh adalah oleh siswa maupun orang tua yaitu dapat dengan mudah bertanya langsung kepada guru ketika tidak memahami materi belajar dan tugas yang diberikan.

\section{UCAPAN TERIMA KASIH}

Terima kasih kepada Kepala Desa Bejiharjo, masyarakat Bejiharjo dan Guru SDN Gelaran I Bejiharjo yang telah memperbolehkan saya melaksanakan program KKN AKB Unida di Desa Bejiharjo Karangmojo Gunungkidul Yogyakarta.

\section{DAFTAR PUSTAKA}

Afandi, M., Chamalah, E., \& Wardani, O. P. (2013). Model Dan Metode Pembelajaran Di Sekolah. In Perpustakaan Nasional Katalog Dalam Terbitan (KDT) (Vol. 392, Issue 2). https://doi.org/10.1007/s00423-006-0143-4

Basar, A. M. (2021). Problematika Pembelajaran Jarak Jauh Pada Masa Pandemi Covid-19. Edunesia: Jurnal Ilmiah Pendidikan, 2(1), 208-218. https://doi.org/10.51276/edu.v2i1.112

Handayani, P. G., \& Hidayat, H. (2017). Pentingnya Pelaksanaan Home Visit oleh Guru Bimbingan dan Konseling. Jambore Konselor, $3, \quad 168-177$. https://www.gci.or.id/proceedings/view_artic le/207/4/jambore-konseling-3-2017

Husnuzzakiya, A., Jalil, A., \& Sudrajat, A. (2021). Implementasi Metode Home Visit Pada Pembelajaran PAI DI MTs Negeri 5 Malang Kecamatan Donomulyo Kabupaten Malang. VICRATINA: Jurnal Pendidikan Islam, 6(8), 4-10.

SKB Mendikbud, Menag, Menkes, dan Mendagri RI, Kementerian Pendidikan dan Kebudayaan 41 (2020).

Isnurani, Ilmadi, Aden, Sastro, G., Valentika, N., Nurbaiti, D., Sugianti, D., Ariffah, N., Lestari, P. I., Oktavian, S., Maesaroh, S., Nurmelani, V., N, V. V., \& Zufikar, P. (2021). Pelatihan Penggunaan Media Pembelajaran Matematika dalam Rangka 
902 Implementasi Metode Home Visit untuk Meningkatkan Motivasi Belajar Siswa SD pada Masa Pandemik Covid-19- Teguh Prasetyo, Endin Mujahidin, Rasmitadila, Aprillia Kumala Yuani DOI: https://doi.org/10.31004/abdidas.v2i4.388

Meningkatkan Motivasi Belajar Siswa. Jurnal Abdimas, 2(1), 121-126.

Mahendra, L. A., Sulistiani, I. R., \& Musthofa, I. (2021). laksanakan secara. VICRATINA: Jurnal Pendidikan Islam, 6(7).

Makmun, S. (2021). Kombinasi Pembelajaran Media Daring dengan Strategi Home Visit pada Masa Pandemi Covid-19 pada Sekolah Dasar Negeri 1 Batu Layar. Jurnal Ilmiah Telaah, 6(1), 20-25.

Mokodompit, I. S. (2020). Home Visit sebagai Refleksi Kurikulum Darurat Covid-19: Kesiapan Guru, Respon Siswa, Materi dan Hasil Belajar di Madrasah Tsanawiyah. Jurnal Manajemen Dan Pendidikan Islam, $6(2)$, 119-131. journal.unipdu.ac.id/index.php/dirasat/index

Nirmala, B., \& Annuar, H. (2020). Home Visit: Strategi PAUD dari Rumah bagi Guru di Daerah 3T pada Masa Pandemi Covid-19. Jurnal Obsesi : Jurnal Pendidikan Anak Usia Dini, 5(2), 1052-1062. https://doi.org/10.31004/obsesi.v5i2.716

Ota, M. K., Djou, A. M. G., \& Numbah, F. F. (2021). Problematika Pembelajaran Daring Siswa Kelas VII SMPN 1 Ende Selatan Kabupaten Ende. Mitra Mahajana: Jurnal Pengabdian Masyarakat, 2(1), 74-81.

Pambudi, R., Prabowo, A., \& Purnamasari, I. (2021). Home Visit Sebagai Metode Pembelajaran Jarak Jauh Pada Masa Pandemi Covid-19. Jurnal Sinektik, 4(1), 63-70.

Prasetyo, T., Lathifah, Z., Sya, M. F., \& Kholik, A. (2020). Program KKN Adaptasi Kebiasaan Baru Untuk Mewujudkan Merdeka Belajar Pada Masa Pandemik Covid-19. Prosiding Seminar Nasional II UNIDA 2020 Penelitian Dan Pengabdian Kepada Masyarakat . Tema: "Menjawab Tantangan Perubahan Iklim Bermasyarakat Melalui Penelitian Dan Pengabdian Kepada Masyarakat, November, 435-441.

Rahmania, S., Maula, L. H., \& Khaleda, I. (2021). Perbandingan Keaktifan Siswa dalam Pembelajaran Sistem Home Visit dan Sistem Daring. Didaktik: Jurnal Ilmiah PGSD STKIP Subang, 7(1), 94-100.

Syifa', L., Nurdyansyah, N., \& Nyong, E. (2020).
Implementation of Home Visite Program in Overcoming Student Learning Problems in SD Muhammadiyah 1 Pucanganom Sidoarjo. Proceeding of The ICECRS, 6, 1-11. https://press.umsida.ac.id/index.php/icecrs/art icle/view/385/259

Yunitasari, R., \& Hanifah, U. (2020). Pengaruh Pembelajaran Daring terhadap Minat Belajar Siswa pada Masa COVID 19. Edukatif: Jurnal Ilmu Pendidikan, 2(3), 236-240.

Yusrizal, Lubis, B. S., Fatmawati, \& Muzdalifah, D. (2020). Pengaruh Metode Visit Home dan Pola Bimbingan Orang Tua terhadap Motivasi Belajar Siswa Sekolah Dasar di Era Pandemi COVID-19. Jurnal Tematik, 10(3), 113-119. https://jurnal.unimed.ac.id/2012/index.php/te matik/article/view/22102/14818 